\title{
No Consensus - Because Why? Interview with Maren Lehmann and Ingrid Volkmer
}

Interview with

Maren

Lehmann and Ingrid Volkmer

\author{
Markus Heidingsfelder
}

Department of Journalism \& Advertising, Xiamen University - Malaysia, Sepang, Malaysia
969 Accepted 9 December 2020
Received 9 December 2020

\section{Prologue}

At the beginning of the 1970s, the German public was introduced to a debate over the correct contemporary theoretical understanding of society. The circumstances leading up to it make it seem almost entirely coincidental. When Luhmann gave a lecture on the sociology of love in Frankfurt, his apparent coldness with regard to the topic - his professional scientific attitude, in other words - was met with a similarly cold reception amongst the politically engaged students there, as a result of which they asked Habermas for a statement. Habermas, who was Adorno's assistant at the time, invited Luhmann to one of his own seminars, with their discussion eventually culminating in the book Theorie der Gesellschaft oder Sozialtechnologie (Theory of Society or Social Technology, Habermas and Luhmann, 1971).

This "Theorie-Diskussion" (as the subtitle of the book clarified) had all of the elements for mass media consumption on a national stage: it met the demands for conflict, and it allowed for the personalization of said conflict in the form of a duel between two great German master thinkers. On the one side was Jürgen Habermas, who demanded that sociology consist in a critique of society - i.e. he considered it a moral obligation to uncover suboptimal social conditions, and identify the means by which to improve them. Taking aim at his antagonist prior to the discussion, he had criticized Luhmann's view of society for being too conservative and for lacking any vision of social utopia, while Luhmann insisted that morality, judgement and social criticism require a theory, whereby he placed particular emphasis on an adequate description of social reality, which Habermas did not provide because he parroted utopias instead of actually pursuing a contemporary sociology, and clung to centuriesold ideals instead of daring to come up with something new. If one subtracted all details, what remained was - according to Lyotard - a rivalry between two models: that of society as a functional whole, and that of the bipartite society (Lyotard, 1986, p. 42).

An interesting aspect of the debate was the fact that truth, from a systems-theoretical perspective: the medium of science, fell precisely at its center; a characteristic it shared with another scientific meta debate of the time, the one between Karl Popper and T.S. Kuhn (Lakatos and Musgrave, 1970). For Luhmann, truth takes on the function of making methodologically sound statements generally acceptable. It is not much more than a label attached to the knowledge gained according to scientific standards in order to guarantee its binding nature. Habermas, on the other hand, understands truth as a claim of validity that is raised by particular actors in communicative action. And although both parties acted rationally over the course of the debate, no consensus between them could be reached. In Habermas' terminology, the ideal to which the claims to validity - as asserted in his theory -

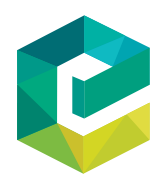

Kybernetes Vol. 50 No. 4,2021 pp. $969-993$ C Emerald Publishing Limited $0368-492 \mathrm{X}$ DOI $10.1108 / \mathrm{K}-12-2020-862$ 
$\mathrm{K}$

50,4

refer could not be approached, and no forceless force of the better argument could decide the outcome of their communication.

Let us for a moment imagine using Habermas's own understanding of truth against him, and suppose that he was mistaken because he had based his social science concept on the false assumption that the intersubjective practice of understanding owes itself to certain preconditions, i.e. that the terms and rules of a language that can be used in an agreement represent, as it were, culturally stored results of earlier agreements (which are then available as such to enable further agreements etc. pp.). Accordingly, understanding would not always have already begun, discourse would not be "coextensive with the history of the human world" (Habermas, 1984, p. 109), and the presumed tension between fact and validity that he suspects to obtain somewhere in the "structural depths" of communication would not be a fact itself. Nothing would force sociology to systematically contemplate the prospect of a "better" world; it would not have to consist in a "critique" of society. Luhmann's "affirmative" approach - his "social technology" - however, would be factually valid, i.e. legitimate. Of course, the opposite could also be true (in the above sense): Habermas was right, and communication is at its core a tension between factuality and validity, which from there permeates the whole of society. Unfortunately, we cannot ask communication if this is true.

The claims to validity raised in their discussion referred to an ideal that would become attainable years later, albeit not in the form of assertions of truth, but rather in the form of a mutual expression of respect. (Of course, that is not exactly the way Habermas intended the concept, but in bridging such an intellectual chasm between the two great thinkers, the achievement is noteworthy nevertheless.) The claim to validity was thus awarded to the person - and not to his arguments. In his review of Habermas's Faktizität und Geltung (Facticity and Validity), Luhmann noted:

However, it should not be ignored that the radicalism and intellectual honesty with which Habermas addresses a fundamental problem of modern society deserves recognition. (Luhmann, 1993, p. 54, transl. M.H.)

As for his rival, eventually goodwill also overcame communicative reason:

Incidentally, I have the feeling that Luhmann - in the course of a long discussion from which I have always learned - has never operated with such a high degree of hermeneutic willingness and given so much leeway to the principle of leniency. (Habermas, 1996, p. 394, transl. M.H.)

The fact that Habermas is writing these sentences as part of a study entitled Die Inklusion des Anderen (The inclusion of the other) is of course a nice - performative - punch line. But to be clear, this cordiality was nowhere be found at first. As editor of their book, Habermas yes, that one, of all people - managed to include a denunciation of the opponent's theory in its very title; by calling it a "social technology," he effectively deprived it the status of a theory and turned into a mere means of vicarious, functional-instrumental action instead. One could argue that the fierce determination that becomes visible here is directly related to the basic assumptions of his theory. However, any "norm commitment" - and be it the commitment to the theoretical norm that communication itself is committed to the value of consent - expects emotions, not because norms (e.g. "We hold this truth to be self-evident, that the claims of normative rationality are valid") are emotional attitudes; rather, it is because such a norm commitment provides a line of defense against the high risk of counterfactuality by corresponding internal attitudes (Luhmann, 1995 [1984], p. 324; see also Goode, 1960, p. 256 f.). As Füllsack notes, "Habermas can probably be accused of overheating his claims to validity in sympathy for "communicative action" from the outset 
[...]" (1998). Having tailored a theory in which this norm commitment was to be found - as it were - in communication itself, he obviously could not help but aggressively defend it after all, the realizability of an idealistic-utopian model of law and democracy was at stake [1]. Shakespeare knew it all along: The best intentions pave the way to Hell. In the case of Habermas, it was the idea that communication itself had the best intentions, so to speak, more precisely: that the pragmatic presuppositions of everyday speech acts commit speakers to resolve differences, which obliged the speaker Habermas to the contrary, to maintain and emphasise the differences, and sharply reject Luhmann's theory as "deficient"

Interview with Maren Lehmann and Ingrid Volkmer und "affirmative". From Luhmann's point of view, the road to truth is paved with something else. It is not permissible to do much more than assume the facticity of a given communication, even if it is the assertion of an ideality that claims validity.

His reaction, on the other hand, to Habermas's maneuver speaks volumes, and makes the difference between the two approaches quite clear. In one of his lectures, he discusses the "ideological burden" that sociology has long suffered:

For example, the discussion I had with Jürgen Habermas at the end of the 1960s/beginning of the 1970s was published under a title that Habermas chose, which I let happen - I thought it had no great significance anyway [...] It imagined a theory of society with certain ideological preconditions; it should exclude everything technical, systemic and the like. These are prejudices that are not self-reflexive. (2009, p. 26, transl. M.H.)

Because both were too busy positioning themselves in relation to the other, they missed out on a remarkable similarity in their theoretical approach, which Manfred Füllsack (1998) has pointed at: Both theories have a blind spot at their center.

Luhmann observes that it is not the current observation but only a further observation (a second-order observation) that can observe the distinction used in the first-order observation - i.e. that every observation remains latent in itself. For Habermas, analogously, it is never the current agreement, but only a further agreement that can problematize the system of concepts used in the first agreement - i.e. make it the subject of an agreement and thus ensure that the concepts were used adequately. The difference between what is currently agreed and the conditions for such an agreement must be concealed in order to remain amenable (to a subsequent agreement). Without this restricted non-restriction or binding boundlessness of the registration of "validity claims" in current notifications, further agreement is simply not possible. As already indicated above, for him the mere possibility of agreement presupposes the uncritical acceptance of the terms and rules of language it already uses. This blind spot is constitutive of the whole process.

Habermas's communication, one could say, cannot communicate about itself for the same reason that Luhmann's observation cannot observe itself. Both have a blind spot exactly at the point where they turn back to themselves and make themselves their own objects. And both dissolve this blind spot in time: Habermas temporalises this unity in agreements, Luhmann in second-order observations. A remarkable analogy that allows us to compare these theories, which at first glance appear so different and incompatible [2].

Personally, too, they were closer than one would initially suspect after the aforementioned inglorious prelude. The two theorists were more than just colleagues; they were friends who often met for table tennis - a fact with which Luhmann loved to astonish his audiences [3]. And this anecdote has spread, not least of all because it attests to the distance between theory and everyday life in a sophisticated and relaxed way.

It may, therefore, not be a coincidence that Luhmann explains the very concept of the sphere - with reference to a quote from Simmel - using the example of tennis, of all things. Simmel had introduced his considerations about social limitation in his essay on the spatial orders of society with the following thesis: "Wherever the interests of two elements apply to 
$\mathrm{K}$

50,4

972

the same object, the possibility of their coexistence depends on the fact that a borderline within the object separates their spheres [...]" (1992a, p. 698, transl. M.H.) However, Luhmann continues, the boundaries that Simmel has in mind do not separate the social system from its environment; rather, they cut through the object according to the difference 'my sphere of influence/your sphere of influence.'

Thus interaction is formed over a boundary, as in a game of tennis. Common zones may be more or less broadly laid out, and everyone may more or less enter into the other's sphere. But finally an intimate domain for the other must be preserved; he must be granted a right to things of his own and to secrets. (Luhmann, 1995 [1984], p. 126)

In this plea for the opacity (or blackness) of the box, is Luhmann talking about himself and his table tennis partner Habermas - the 'Spheres Man'? Probably not. (It is tempting enough to pursue this assumption for a moment, though. I know of no other place in Social Systems that invokes the concept of the sphere. In the English translation of the book, "Interdependenzkreise" [1984, p. 344] - literally, 'interdependence circles' - was understandably translated as 'spheres of interdependence' [1995, p. 254]. The 'circle of life' ["Lebenskreis", 1984, p. 287] also ended up as a sphere [1995, p. 211], living up to the fact that the term denotes something that is ball-shaped; what the reader encounters as "sphere of experience" [1995, p. 430] in the English version are "Erfahrungsräume" [1984, p. 585] - i.e. spaces of experience - in the German one. This problematic spatial aspect of the term is no less echoed in the context of the concrete manifestation of the public sphere that Habermas cites: the salons and coffee houses of the 18th century. Luhmann does not mention these spaces of experience here by chance; on the contrary, he aims to demonstrate that no interaction - regardless of how high ranking the persons involved may be - can claim to serve as a representative function for society - or, in other words, to be a public sphere in the Habermasian sense, as described in the introduction.) But it does offer a counter argument to the Habermas's accusation that Luhmann's theory is bereft of moral principle; it is the black box itself that should be considered one, Luhmann argues, quoting Simmel once more: as the "private property in the soul's being" (1995, p. 126).

While Simmel is not our focus here, it is pertinent that he was interested in a variant of the black box principle of mutual inscrutability. We know (thanks to psychological hypotheses) more about each other than we are inclined to reveal, but thanks to the limitations cited, we must concede that the other wants or does what the other wants or does. It is fair to say, then, that here Simmel - albeit in somewhat ambiguous terms - is concerned primarily with the organisation of the connections between interrelated psychic systems. Luhmann further observes that the boundaries Simmel describes do not belong to the organization of psychic systems - just as in tennis one sees one's opponent, but is not allowed to run to the other side of the field or, in ping pong, the table - but are already an element of the organization of the social system. Moreover - and this is the decisive point for him - this provides a solution (and reproduction) of the problem of double contingency which this section of Social Systems is about.

The net on the court (or table) organises a tennis game to which the players can assign themselves without fear of getting stuck in the problem of double contingency: everyone knows when it's his or her turn, and what is and is not allowed, and when the game is over. Explicitly stated, it is not people who draw boundaries, but boundaries that create people (Luhmann, 1995 [1984], p. 127)! Awareness does not, therefore, precede the circumstance of choosing appropriate system references. According to Luhmann, there is no consciousness without these pre-constituted boundaries that act as catalysts for the formation of consciousness. Only when consciousness realises that it is confronted with the demands of 
several "spheres", i.e. systems simultaneously can it enter a state of reflection and ascertain the possible choice of one system reference at the expense of another - e.g. sports, not science law, not politics; intimate system, not economy; or (in the terms of communication media) truth, not power.

As in Habermas's work, the magic word 'sphere' creates some of the confusion. After all, we can talk about the spheres of two interests in one and the same object. Simmel infers from two (or more) spheres to two (or more) individuals interested in this object. Analogously, he says, "Here are two (or more) spheres!" From these he deduces two (or

Interview with Maren Lehmann and Ingrid Volkmer

973 more) individuals interested in the object. If Luhmann were to use the term sphere - which he decidedly does not, and if he does, then only to use the term as a synonym for system and to oppose the idea of an organ-like public - he would be referring to the disputed object as the focus of one sphere of a social system. This sphere of the system would then be organized with sufficient distinction and variation to be capable of differentiation and reproduction, as well as offering individuals different points of departure for their own differentiation. If you want to go for a drink together after a tennis match - or meet online for a World of Warcraft gaming session after an exhausting interview on 'shifting spheres' for Kybernetes - you have to change the (social) sphere [4].

Luhmann's interest in this example of Simmel's might concern a thought that - even if it seems completely alien to Habermas - is obvious: If the interest in establishing spatial boundaries is merely a special case of the general interest in distinction and designation (e.g. my playing field vs your playing field, my skateboard vs your skateboard, right vs wrong, distinctions between ethnic, social or religious groups, etc.), then conflicts (dissent, even war) also begin to look like moments of socialization. In that way, the socializing power of conflict appears to lie in its ability to differentiate. As Simmel explains elsewhere:

Hostilities not only prevent demarcations within the group from gradually blurring - so that they can be consciously cultivated as guarantees of existing constitutions but beyond that they are directly sociologically productive: they often give classes and personalities their mutual position in the first place. (Simmel, 1992b [1908], p. 289, transl M.H.)

Their social identity follows hence. Simmel's approach is modern in exactly this sense: the social identity of individuals as well as of groups is no longer understood - as, for example in Tönnies's work - as a harmonious merging of the individual in an organically understood community, which only recognizes dispute, dissonance, division, etc. as a deficient mode of social being, and as such, a threat to its ideal and natural essence (Lüdemann, 1998).

It is this theme that Luhmann revisits. From both of their points of view, conflict is not dysfunctional; it does not entail a failure of society, as if non-conflict or consensus was some sort of a priori goal. From a systems theory perspective, society and its subsystems have only one aim (or "interest"): to continue reproducing themselves. Conflicts make this continuation of society possible, despite and precisely because the normal path is blocked. In the case of the law, they are even constitutive. These constitutive qualities of conflict can also be observed with regard to the question of state-foundation (Heidingsfelder and Lehmann, 2020, p. 143), and in our everyday lifeworld, too - there is always someone who disagrees with something.

Much has changed since the Habermas/Luhmann debate took place. It seems to belong to a time that is now long lost, not least because the public is no longer occupied with highly abstract scientific topics, such as the question of an adequate social theory (Quod omnis tetigit, as if!). The fact that virologists currently play such an important role publicly has little to do with viruses being such remarkable quasi-organisms, which have joined us in a quite extraordinary and productive symbiosis (as we all know, they can also have lethal 
$\mathrm{K}$

50,4

974

consequences for members of our species, as for example in the case of the novel Corona virus; but only a very small fraction of the viruses that surround us actually pose any threat to us). It can rather be attributed to how science is 'sold' in the mass media: the model here is technology, the idea of the measurable, the calculable, which is then licensed as 'real' - and the dead and available hospital beds can be counted excellently. Technological knowledge (the development of a vaccine or biotechnology belongs here as well as the modelling of example scenarios) is not affected by this decline in authority, which the social theorists just like all other experts - have had to accept. A vaccine either works or it doesn't work, regardless of the type of society in which it is put into service. But virologists and epidemiologists cannot answer the many questions connected with the 'Corona crisis' - and this seems to have dawned on the mass media as well (a first attempt to compile answers from various scientific disciplines beyond virology can be assessed in Heidingsfelder and Lehmann, 2020).

Probably the most important change concerns the fact (also discussed in the introduction) that the once dominant public infrastructure provided by mass media has, with increasing competition for our attention, lost much of its importance. As a result, the idea of a uniformly comprehensive public space was fundamentally relativized.

It is this type of changes in the infrastructural conditions of communication that Ingrid Volkmer is primarily interested. An expert in Habermas's theory of the public sphere, as well as generally well-versed in his work, Volkmer does not simply attempt to "update" our understanding of the Habermasian notion of the public sphere; indeed, when I asked her whether she somehow sees herself in his succession, she vehemently denied it ("God, no!"). But it is with good reason, because she in fact charts the new, contemporary "structural transformation" of the public sphere. For Volkmer, it is the way that individuals and organizations communicate across diverse platforms that defines the global communication of the world today, and thus creates a multiplicity of micro spheres that operate across national contexts, constantly blending the local and the global. But what happens to the legitimizing role of publics when they are dispersed across many discursive sites, and so thoroughly decoupled from the state? What does it mean when the 'macro sphere' that was supposed to connect state and society has, as in Marx's infamous imagery, melted into thin air? Which new models can be identified that have emerged throughout the course of this structural transformation, fueled by globalization and digitization? [5] The connection between her approach and that of Habermas lies in the fact that she is also concerned with making concrete proposals for the elaboration of new frameworks for transnational data policy, and in this sense, acts as an active citizen - not just as an observer. She is a 'globalist' who, as a global public communications expert within the framework of the IPSP (International Panel on Social Progress), recognizes the potential transnational research globalization has made available, in order to provide governments worldwide with policy frameworks that address the major social challenges of this century - from climate change (see Robin Robertson's contribution in this issue) to the fragile character of the world risk society we live in.

As it quickly becomes clear in her discussion of publicity at the start of this interview, Maren Lehmann - nomen est omen - takes her starting point from the operative unity of systems, like Luhmann; no system can cross its own borders and operate outward into its environment. National borders, however, are no real obstacle (nor are they for communication in general, which is one of the few things it has in common with the virus). Every system operates 'on the inside' of its borders, even if it is capable of identifying other systems on the outside. How can the public be thought of in accordance with such a design? Perhaps as a reflection of inner-societal system boundaries? As a generalized "other side" of 
all social systems that each have their own distinct environments? This is Dirk Baecker's proposal (Baecker, 1996; see also Luhmann, 2002, p. 285), and this is from where Lehmann's concept appears to take off. However, she accentuates it in a notably different way when she models publicity as communication across borders. What interests Lehmann in this context is not only the problem that in modern society only one system decides about the consideration and rejection of claims or demands, namely politics; but most of all which media limit this public communicating across borders, i.e. in turn erect new borders and thus create new environments, and whether mediaspecific forms of a 'public style' can be

Interview with Maren Lehmann and Ingrid Volkmer

975 found here - genres of publicity, if you like. But the theoretical figure of the system only plays one role among others in her recent work. Lehmann increasingly explores her object the possibility of social order - with the help of two other key concepts: contingency and complexity. Both her inclusion of and modification to Baecker's definition clearly shows that her commitment is to no particular school of thought, but rather to a consistent theoretical design (with the emphasis on design, which is one of her principal interests outside of sociology), which she realises in a precise but deliberately provisional form: as a 'theory in sketches' (one of her book titles).

Should the reader wonder why I am able to refer to both scholars by their first names throughout the text, I've worked with Maren on several occasions, and Ingrid has been a good friend of mine since I started teaching at Xiamen University Malaysia (Australia is right around the corner). So, in the interest of some transparency, I must confess that the simple fact that I was able to persuade them to collaborate with me on this special issue without too much trouble played no small part in their ultimate presence here. However, there was another consideration that I believe has proven far more valuable to the project than the matter of my personal convenience. This issue was intended to center around the concept of the public sphere, and my co-editors and I wanted to feature a Theorie-Diskussion in a prime spot within it. And while the theoretical texts themselves also enter into a kind of dialogue as a matter of course, there is something special about a literal conversation when it comes to capturing the peculiarities of scholars' different ways of thinking. Idiosyncrasies come to life right before our eyes, individual attitudes can't be as easily hidden as behind densely formulated texts, and the subject matter becomes more accessible to the reader, too - without losing its complexity, in part because of how vivid the contents are able to become in this format. Ultimately, this interview is both an addendum - a postscript - to the aforementioned 'theory discussion' of the past, and it is not. At first glance, Volkmer and Lehmann are easily categorized as taking distinct theoretical positions and belonging to competing schools of thought. In one corner, we have a media sociologist who is personally acquainted with Habermas, and whose work focuses on transnational approaches to digital policy and the development of new frameworks with which to treat them; on the opposing team, we have a systems theoretician and direct successor to Luhmann (a not insignificant biographical detail: Lehmann first began writing her dissertation under Niklas Luhmann, who died before it was completed).

Déjà vu? Only because you 'lived through' similar lines before. With this interview, we hoped to make palpable just how much has changed since Luhmann and Habermas crossed swords. Two twenty-first-century women - both in leading positions at their respective institutions - replacing our twentieth-century male pugilists is the sign of the times that is perhaps most glaring. But while the differences in the theoretical starting points of both the 'opponents' are obvious, something subtle is also revealed. As Füllsack noted more than twenty years ago - apparently surprised by the discovery that upon further inspection, allegedly incompatible positions of Luhmann and Habermas had more than a little overlap between them -: the fronts need not be so rigid. Fortunately, we have put the alternative 
$\mathrm{K}$

50,4

between two models - this methodological divide once highlighted by Lytoard - behind us. Maren Lehmann does mention in the interview that she did not actually find the alleged normative opposition of the two approaches - and even more so, Habermas's opposition with "every other theory proposal" - in his books. On the contrary, she argues that "these largely dissolve when reading Habermas." To put it even more bluntly, there never was a front: "Habermas's theory was used as ammunition in the fight against rival theory schools; this had nothing to do with his books." In hindsight, the half-century old debate seems to share much of the same spirit as the Cold War period. Now such certainty feels more like a kind of 'microwave background': it still radiates enough warmth to create a cozy feeling, but is no longer so hot that recombinations are impossible.

Neither of the two participants set out to 'duel.' The following conversation is, to quote a Friedrich Schleiermacher statement, "a convivial place to live and let live" - a place wherein the problem of the concept of the public sphere is grasped without the intention to be right; that cultivates the simultaneous presence of different concepts and thus functions both as an introduction and commentary to the question of shifting spheres, including a nice punch line at the end.

For obvious reasons, the conversation is more static than a face-to face conversation could be, even if we did try to simulate such a 'physical simultaneity' here and there. Its static character is based on the fact that the same set of questions were initially posed to each participant separately from the other. In a second step, Ingrid and Maren were able to view one another's responses, which made mutual reference possible - and the style much more conversational as a consequence.

I would like to thank both Ingrid and Maren very much for their participation, as well as 'joker' Michael Hofmann - whose work is also featured in a separate article in this issue for a postscript to this postscript that adds a specific 'Habermasian' perspective to the question in how far other formally similar sphere concepts by Habermas can be updated today, if at all. Let me end this introduction with a quote from Nietzsche that appears in one of Maren's lectures (a lecture on lectures, actually):

The reader from whom I expect something must have three qualities: he must be calm and read without haste, he must not always put himself and his 'education' at center, he must not expect tables at the end, for example, as a result. (Nietzsche, 1999, p. 648, transl. M.H.)

In our case, he - or she - must not expect a consensus, because - as the title of this text already anticipates - why?

What is your conceptualization of the public sphere?

Ingrid: Despite the density of transnationalization of communication, we are only beginning to understand the implications of this new sphere for public communication and civic deliberation. However, when attempting to conceptualize this sphere of public space, we face an ambiguity: on one hand, conceptions of the 'public sphere' are still dominated by approaches that conceptualize this new transnational public space through an overarching dominant modern paradigm, and the 'ideal' of public communication as it has been conceptualized in the tradition of European nations.

One of the key points of my work is to emphasize that the way how we understand 'public' spheres and public deliberation has to be disentangled: first of all, from these traditional conceptions of national boundedness of public debate, and second, from the paradigm of the European nation-state, which is the key focus of Habermas's work. It is important to realize that Habermas's concept of public spheres and also of public 
deliberation is deeply embedded in the Western European nation-state, and - through this relates to processes of deliberation to enable legitimacy and accountability.

However, first of all, the reality of public life is different today:

public communication is no longer 'local,' 'national' or transnational, but rather unfolds across a sphere of globalized 'reflective' interdependence where citizens in Amsterdam engage with political issues directly along with citizens in Nairobi, Sydney and Kuala Lumpur, and engage in new types of transnational discursive 'axis' unfolding across dynamic, 'lively' and sometimes 'viral' digital spaces of ad hoc publicness that are no longer

Interview with Maren Lehmann and Ingrid Volkmer bounded, but meander across societies. My work has a focus on these processes, and my book on the 'Global Public Sphere' identifies these new types of civic interaction as processes of reflective interdependence. These are very fine lines of discursive interaction that unfold in a new public horizon. A new public horizon wherein the core domains of communicative reasoning (from Kant to Habermas) - such as 'justification,' 'verification,' 'engagement' - are no longer necessarily embedded within the bounded discourse of national debate, but are scattered across different discursive sites within globalized communicative horizons. These spheres of reflective interdependence are positioned in the trajectories of such a 'scattered' territory of public communication that not only overcomes national borders, but breaks up paradigmatic boundaries of the global 'North' and 'South' the 'center' and 'periphery.' In my book, I argue that publicness in the formation of transnational reflective interdependence enables discursive interaction across societies and transforms not only conceptions of civic and public engagement, but also paradigms of globalization - and of 'civil' society - in international relations and world citizenship.

Second, we also have to realize that ideals of public discourse also exist in other world regions. In African contexts, the ideal of 'ubuntu,' of local community 'deliberation,' reflects the traditions of local civic debate in many African countries. In China, the Confucian idea of 'harmony' is the underlying conception of discourse ideals. In world where civic interaction enables political discourse among citizens across world regions, we have not only to acknowledge these different traditions, but also to include them in the conceptualization of the way in which these different discourse ideals are reflected in discursive axes between citizens from different regions now engaging with each other. Further questions include how such a civic interaction begins to shape a new horizon for 'legitimacy', sovereignty and - of course - deliberation. Overall, my work aims to conceptualize this new public architecture that evolves as a 'networked' space of civic interaction across all types of societies. I describe these new fine lines of reflective interdependence as 'microspheres' of direct civic interaction in a transnational sphere.

Maren: Perhaps I would say in general terms: the public sphere is a form of communication across borders, which has its meaning in the opening of these borders. Gregory Bateson once remarked that borders are not walls, but bridges; and in this sense publicity is a bridge concept. If publicity is possible - that is, if communication across borders is possible - then social environments can no longer be understood as closed internal spaces. Presumably, this presupposes the possibility of observing these environments not only from the inside - because then they appear as surroundings, or as the environment of one's own gaze - but also from the outside - or, as if it were from the outside - in a mode of criticism or protest. For me, a certain public sphere has already arisen whenever people observe each other - even if they are only perceiving each other - because this pulls them out of the shell of their attachments. In this sense, the public sphere would be something like the counter-concept to idiosyncrasy. And more specifically, publicity is the space - the sphere - in which observations cannot be discredited, cannot be put under suspicion, cannot be rejected. In this more political sense, the public sphere would be 
$\mathrm{K}$

50,4

978

something akin to the counter-concept of the private. If one generalized this consideration i.e., if one considers communication across borders as a system form of society and discusses it for functional systems as well as for organizations, families, systems of interaction - it could be argued that there is no system that is not public, because there is no social system that is not observed and across whose borders there is no communication. But it would still be a specific political problem, because politics is the social system that deals with the consideration and rejection of claims or demands that may result from observations. Perhaps that would be a null statement - a simple derivation from basic assumptions of systems theory - for the time being.

Ingrid: Yes, I agree, but media extend and limit the public sphere at the same time, don't they?

Maren: Of course, and most of all, media differentiate the public, meaning that media increase the complexity of the public. It gets interesting when you look at the limitations of the media the members of this public, as they communicate across borders, have to come to grips with: Books, press, radio, television, internet, so-called old and so-called new media, etc. Their limitations show that the public sphere is limited in a specific way: it creates environments of its own kind - selective medial ecologies - that remain public as long as they observe each other, or even just communicate across their own boundaries. This is often criticized or reviled as a media's self-reference - indeed, as their empty self-reference. But it is the prerequisite for being able to talk about the public sphere at all. The media observe the media; this is communication across borders, too. I am very much concerned with the question of how individual media differ in this respect - whether there are, so to speak, media-specific styles of publicity.

How do you relate your conceptualization of the public to the one introduced by Juergen Habermas?

Maren: What has always interested me about Habermas's concept is its trust in critical reason. In a kind of - if you can put it that way - friendly faculty of discernment (zugewandtes Unterscheidungsvermögen). And also in a reserved - or, more precisely, in a neutral - willingness to participate. That makes a lot of sense to me, but it makes sense to me as a desideratum. I wish that for myself, too; it would be wonderful to find something like that. It would be like you were really among friends - among kindred spirits - precisely because you'd be more likely to face opposition than approval. It would be indescribably beautiful, not to be excluded when contradicted, nor to be excluded when not understood. But can a desideratum be a concept? How normative - i.e., how exclusionary - are the basic rules of reason and willingness to understand? How corruptible is reason? Is the ultimately political public sphere of critical discourse, that Habermas hopes for and that I also hope for, not undermined by a seduction to belong? Or, precisely, to be recognized? To be heard and seen? Doesn't readiness for discourse presuppose the ability to discourse - i.e., discursive education? And isn't this precondition at the same time a culturally exclusive code, such that understanding functions as currency in a struggle to gain distinction, and suffocates criticism?

Ingrid: The reliance on the Habermasian paradigm - mainly related to Western world regions - has left us with two gaps that become crucial today. Firstly, a lack not only of alternative historiographies in Western world regions, but especially knowledge of specific understandings of public culture and its transformations in non-Western world regions. The unfolding of the public sphere is seen through the angle of traditions of European public life, and its ideal is related to the bourgeois salons of the 19th century; there isn't much knowledge or historiographies about trans-border public spheres. This is all the more surprising given trans-border 'flow' is not a phenomenon of the 20th or the digital life of the 
21st century, but has existed for centuries, especially since the time - often overlooked - of the invention of the printing press in China and Europe. In my view, the gap in historiographies of regional traditions of trans-border public life and deliberation makes it really, really difficult to conceptualise public communication in non-Western world regions now. In my book, I outline an alternative historiography to the Habermasian Europeancentered approach by addressing historical public trans-border historiographies as they have existed since the time of the printing press in very different ways across centuries. We actually clearly already see conceptions of 'trans-borderness' from African and Asian regions and also in Europe in the late-medieval and the Renaissance period. Of course, colonialism added an additional layer of new perceptions of political power and sovereignty that deeply influenced perceptions of trans-borderness. These processes cannot be ignored when we discuss transnational public spheres today.

Secondly, my work departs from Habermas's notion of the boundedness of national procedural 'mechanisms' of public deliberation. I argue that such a boundedness has become porous for decades and, actually, for centuries. Particularly today, we need to address the holes in the traditional national conceptions of a boundedness of publicness. Not only are public communicative forms 'disembedded' from national territories, but core assets of public 'civil' culture - public institutions - are situated within polity regimes of transnational accountability, ranging from legitimacy of political 'civil' action of governments - e.g., elections, as well as previously non-transparent spheres of intergovernmental relations - to forms of deliberation. In addition, today's transnational terrain of 'civil' action and reasoning is situated within - and magnified through - a transnationally available spectrum of choices, loyalties and political alliances. Not only is it possible to engage with digital activism from almost anywhere through digital access, but this spectrum has become more 'horizontally' subtle:

I can live in Australia, vote in Germany, read news resources from the US, watch streaming television from Kenya, and engage in 'live' debates about saving the Amazon rain forest with NGO's in Latin America. These are the new geographies of public 'horizons' that are - and this is important to realize - no longer central to the democratic nation-state, and they are also no longer central to other societies either! It is a shift towards a subjective axis determining and selecting engagement in a globalized interdependent public debate of chosen networked formations that has implications on deliberation and legitimacy - again, in a geographically 'horizontal' spectrum. In a way, it is the new calibration of 'polis' and 'demos: my vote contributes to the election outcome in Germany, but I take on roles in climate change communities in Australia that are no longer informed by local knowledge or the climate change agenda of national media, but rather by subjective public horizons. These are issues that have to be central to public sphere debates, and my book tries to initiate such a debate.

\section{When did you first come across Habermas's conceptualization?}

Maren: Not in critical public, if I may be so bold. But rather in the course of university study, where he was used normatively and turned against every other theory proposal (especially structuralism, ethnomethodology, systems theory); however, these largely dissolve when reading Habermas. Habermas's theory was used as ammunition in the fight against rival theory schools; this had nothing to do with his books. By the way, this is actually possible if you understand a seminar in a privatist-particularist way, 'We do it this way and that way.' But if you understand it as the 'form' of the university and take it seriously as a public sphere, then it's just not possible; then theory proposals cannot be rejected, but always end up on the table for discussion. In 
$\mathrm{K}$

50,4

980

this respect I must say that I encountered Habermas's theory in contexts that contradicted his theory proposal. But you learn a lot from that.

It is now twenty, almost thirty years ago, and today I encounter Habermas's theory which varies greatly, the concept of the public sphere hardly plays a role anymore - as well as Luhmann's or Foucault's theory as a striking or bold cipher that somehow hearkens back to a sociological golden era. And then I also encounter Habermas's concept of the public sphere as a melancholy warning, so to speak, because the forms of criticism and protest practiced today are often so narrow-minded, idiosyncratic, and communication-averse that I think practically every day about how attractive and at the same time improbable his concept of the public sphere probably is. A dream.

Ingrid: The normativity of the Habermasian paradigm is still so evident today. What do you think, why has it become too powerful? What kind of links do you see to Luhmann or Foucault?

Maren: As I said, all three are used as ciphers to build argumentative blocks, and that was not their intent. It's about theory, and this seems strangely old-fashioned these days. These days it seems like every conflict has to turn into a fight, and - but this is, of course, sheer speculation - now Foucault would have agitated it, Habermas would have moderated it, and Luhmann would have ironized it. The more complex and contingent a society becomes, the more likely it is that this society will constantly vary its own order and weaken its integration. The temptation of normativity increases, because that way, complexity can be reduced and contingency can be managed. Foucault would have reminded us of the social costs of such normativity - that is, that it leads to exclusions that just kick the problem across a border and tries to fix them over there. Luhmann would have recalled the advantages of a certain affinity for change - that is, the possibility for social and individual learning. He would have preferred cognitive rather than normative expectations in that way. And to this day, Habermas never gets tired of reminding us that a communication disposed to moderate is far more sustainable than one disposed to fight.

Ingrid: Having studied social sciences in Germany, Habermas's work and Critical Theory as such was central in numerous ways. From understanding the role of media in a democratic state to drafting media literacy, from understanding 'communicative action', the dialectic of modernity to the discourse of law and democracy. Critical theory as such has contributed to the intellectual climate and the building of a 'new' Germany after Fascism. It is interesting to note that Habermas's public sphere book was published in English much later - in the early 1990s - and has enabled a completely different debate. It is surprising that this book still dominates debates of publics today. I had the privilege of meeting Juergen Habermas over dinner, and he told me that he is surprised himself. The emphasis on discourse ethics is still important today; however, what discourse is requires a new conceptual approach - especially in contexts of transnational 'publicness' and contexts of digital communication.

To paraphrase Mr Schudson:

Was there ever a bourgeois public sphere? And if so, when?

Maren: But yes, of course - at least in a practical, pragmatic sense - especially if one uses Habermas's term. The question must be, for whom did it [the public sphere] exist? And for whom did it not exist? For the educated it existed, for the economically secure it existed, for the city dwellers it existed. Perhaps one might actually speak of the bourgeoisie. I would make the latter restriction: the modern-probably only the modern-city is a prerequisite for publicity in a practical sense, because the big city is the social form that considers borders to be bridgeable. So, publicity probably did and probably does exist for educated, economically 
confident urbanites - and among them, in its academic form, for university students - and for them it still exists. The public sphere of rural-small-town life, as far as I can see, is always privatistic, always particularistic. But education also has an effect in the big cities also, and perhaps especially, education for criticism - exclusively. People who cannot read, write or calculate are excluded to this day. People who are considered strangers by perception are excluded to this day. We have to take it seriously that criticism is usually inflamed by what is understood - that is, it has a certain bias in favor of the familiar and the customary. What is foreign may be praised but not critically appreciated. People who cannot decide to be sober and practice tactful self-control - and these are not drunks or exalted people, but people in fear and existential need or in a panic-like insecurity - are also excluded. For all of these people, there is no public at all; for all of these people, borders are existentially closed.

Ingrid: I do not think that we can use the term public sphere as a normative approach, especially when addressing transnational interactive trajectories. Especially in a globalized world, research is required to assess the very different narratives and practices of publicness. However, today research still often has a focus on Western world regions and developing countries where we currently see a major shift into digital communication, and civic practices are often left out. The tunnel vision of only one paradigm of public sphere needs to be overcome.

Which recent shifts related to the public are the most interesting ones from your research perspective?

Ingrid: The new awareness of globalized risks is shaping types of public interaction and deliberation that are fully embedded in digital spaces - especially among today's young citizens across societies. 'Fridays for the Future' is an example of such a new globalized perspective where the engagement on the global level enables a new dimension of 'legitimacy,' wherein action (or, as it happens, non-action!) in global climate governance relates to direct engagement with national governments. Public debate is fully deterritorialized in these new thematic contexts of globalized crisis issues, and deliberation shifts toward direct interaction with policy makers.

Maren: Lately I have been dealing with the question, oriented by Luhmann's notion of the disinhibition of communication, of whether the so-called new media - i.e., especially the Internet and, foremost, social media - are something like negation machines. I am inclined to suspect a certain weakening of the social and especially the material dimension of meaning in favor of a strengthening of its temporal dimension, and to expect a form of communication emerge or spread that is based on sheer operativity. Then slowness, hesitation, brooding, limbo, ambiguities, etc. would all diminish in value, while speed, sharpness, action, decision, etc. would take precedence. In contexts like those, negations are suitable for provoking next steps - i.e., forced operativity - without having to engage in objective considerations and social evaluations. To use an analogy: the Internet - in fact a network - would then appear as a metropolis that is relatively socially anonymous and factually indifferent, but temporally extremely fast. A universalistically observing, rapidly consolidating metropolis that differentiates platforms that follow a particularistic bias. A critical public sphere in the way Habermas's intended would probably get lost in a network like that. Its meaning wouldn't be comprehensible.

Apart from the analogy, the internet is not a big city, so why use the conditional? Why be so cautious?

Maren: Because 'the net' is not a sub-complex matter. My assumption could be true in some respects, not in others, etc. That is clear. I speculate because I know too little, and that ignorance includes the question of whether the concept of critical publicity must be bound to 
$\mathrm{K}$

50,4

982

objective rationality in the sense of a possible understanding. The Internet, or digitalized communication, for example, takes the self-reference - the stubbornness - of communication much more seriously than analogous spaces, even if only because in entails referring to concomitant evidence of perception that you see at first glance - so to speak - and learn to recognize who belongs - i.e., who is allowed to speak - and who does not through subtle codes. This results in a tolerance for strangeness that is familiar in big cities - a tolerance of indifference and anonymity, a tolerance of ignorance and arrogance, but nevertheless a specific opening for the unknown and the stranger to participate. Habermas's concept of participation is certainly more emphatic; he does not intend such ignorant generosity. It seems to me that this is a theoretically open question, but an interesting - even exciting one at the same time: Can there be understanding, can there be criticism, can there be a public sphere in this sense that trusts understanding as a modus operandi of social integration without being deprived of its means by the discrediting of objectivity - as, in my opinion, it is in digital communication, even if only because its tremendous speed overwhelms reflection? This opening - in the sense that it is no longer only the urban, economically sovereign, highly educated classes familiar with the relevant subtleties of cultural coding that participate in the discourse, but that participation in it means interweaving within a network that observes the self-reference of communication - this opening of the public sphere, as one may call it, is already attractive, isn't it?

In addition, we know from analogous communication how seductively attractive the intensification of such observation is for action; opportunities arise for attribution, success and identity. In this respect, the public sphere of the Internet is conventional, in my view. It is particularly susceptible to seductions like that, but that makes no fundamental difference with regard to what we already know.

I came across a wonderful quote in the preface to the 1990 issue of Structural Transformations. With regard to the ambivalence of modern society, Habermas writes, perhaps he would approach the investigation differently today. Maybe he would be, and I quote, "less pessimistic, less defiant and less postulating than back then." Any comments?

Maren: Well, that strong personalization flirts with the assumption that he was a youthful hotspur with certain uncompromising tendencies. The relevant passage itself is unpretentious because it says, I would not do this today, because I no longer know what the point of it would be.

Ingrid: What a shame that he did not revise the original concept.

Where do you see a self-implication at play in Habermas's work? He never talks about his book on the public sphere as being a public affair itself, for instance.

Maren: I have no reservations at all about this point. I think you could follow Weber here with his remark that science cannot be value-free precisely because of autologous complications - you cannot sit on the outside of the world in order to judge the world from there (because this judgement itself would be world form), and you cannot sit down on the outside of society in social theory and sociology in order to speak about society from there (because this speaking would itself be social form), and therefore, you must abstain from judgmental statements or normative advice. That only means that in science, this abstention reappears as reflection. I would say that Habermas emphasizes this reflection when he addresses the normativity of his theory. That he would only do this strategically, so to speak, in order to avoid predictable censure - that may be. But it seems to me to be the usual scientific practice. Because, what else? You anticipate an objection, and you counter it.

Ingrid: When you look across Habermas's work you find numerous lines that suggest a 'self-implication,' as you say, or reflexivity. As my work has a specific focus on transnational public deliberation, I specifically refer here to remarks that reveal an attempt 
to identify new phenomena of discourse practices that require further exploration. Yet, it is difficult for him to conceptually engage with these phenomena. His philosophical orientation towards European modernity- enlightened discourse practices are deeply associated with the traditions of a democratic nation-state. For example, Habermas himself has noted some conditions under which the 'inclusion of the other' is possible. However, given the variety of communicative spheres we observe today, which unfold in often deliberative interactive engagement among citizens not only from different countries but also relate to different traditions of 'public utterances,' the conditions under which these interactions can be called 'rational' are very different from the conditions Habermas outlines. Yes, you might argue that that these practices do not reach legitimacy in the Habermasian sense. However, it might be important to relate not only to national modern nation states and their procedures for reaching legitimacy. These transnational 'utterances' reach legitimacy vis-a-vis globalized risks, for example, and suggest a new dimension of deliberative legitimacy that is reached in transnational discourse but then relates back to legitimacy issues in national governance procedures. For example, transnational debates about climate change influence the way young citizens develop a critical understanding of their government policy measures. So the interactive 'inclusion of the other' requires more attention from these kinds of transnational interactive 'utterances.' The conditions of the 'inclusion of the other' in multicultural societies where social media fracture public debate into thematic communities and in new types of transnational debates are very different. Furthermore, public spheres are often narrowly conceptualized as reasoned discursive terrains; however, they are not always 'reasoned,' but incorporate quite diverse forms of public discourses. These forms of digital discourse also relate to new forms of 'interactive code' that are important for young citizens today. The large protests by young citizens across Europe last year regarding the EU's attempt to implement stricter upload filters on Youtube to restrict the use of 'memes' and other visual interactive features reveal how strongly young citizens feel about these new political discourse dynamics as their generational space of deliberation. So, while a normative idea of public deliberation is necessary (for example, for the regulation of civic space), we should aim to discuss the ways how deliberative practices change across generations of citizens.

In this foreword from 1990, Habermas justifies his decision of not changing the text by pointing at itts status:

It has become a kind of textbook; it has 'naturalized' itself in very different courses of study. To borrow Carly Simon's lyrics for a moment: He's so vain, isn't he?

Maren: Well, clearly the latter aspect is vain - and also because, in a way, it underhandedly makes fun of students. But on the other hand, you have to be able to face the repercussions. And isn't it true that the mockery of the university's longing to finally 'let classics be classics' and not have to constantly work out new aspects of it - in other words, not having to modify module descriptions every six months - is well deserved? Apart from that, it is quite clear that a published text will not be changed; it is the purpose of publishing to make it binding. Once you have published something, there is no way of influencing how you are quoted. Once you have published something, there is no way of freeing yourself from responsibility. It makes sense to me. The aforementioned renunciation is by no means motivated by labour-economic concerns. It's just journalistic seriousness.

Ingrid: As I mentioned earlier, I had the privilege of meeting Jürgen Habermas and talking to him regularly over the course of three months. I cannot express how deeply impressed I was by his scholarly attitude. His modesty when fully engaging on eye-level with $\mathrm{PhD}$ candidates and junior colleagues reveals a true scholar. So, while his approach to public deliberation is seen as 'normative' in numerous disciplines, his own attitude is 
$\mathrm{K}$

50,4

984

inclusive - always open-minded to be able to rethink theory based on societal development. I am sure he would completely reject the notion of being someone producing a textbook type of normativity. While modern rational deliberation as a normative ideal of democratic processes is at his core, to be seen as a scholar producing a normative conceptual approach that is no longer engaging with new debates is not, I think.

At the beginning of Structural Transformation, he says the book will only deal with one form of the public sphere, the liberal model; it excludes both what he calls the "plebeian public sphere' as well as the 'regulated public sphere' that we find in authoritarian states. Should we pay more attention other forms of the public sphere in the present situation - for example, with regard to the socio-political dynamics playing out in the United States (in what some observers call the Trump counter-sphere), Russia, Turkey, or China?

Ingrid: I feel we have to in today's world. Eurocentrism needs to be overcome. We are facing a new type of globalization that is no longer driven by the old geopolitical order wherein normative ideas are produced in Europe and the Western world. We live in times of dense globalized interdependence, and this needs to be reflected in theory and in research. We have to be inclusive and revise our traditional concepts along those lines. We need to aim to understand and not prejudge through the traditional Western perspectives. This does not mean we overlook tight digital surveillance in China, but we need to understand the deeper sense of civic practices and cultures of deliberation to 'dig deeper.'

Maren: True, but neither in China nor in Russia are we dealing with "plebeian" observers; both countries are extremely ambitious, self-confident education-oriented nations, to say the least. The populist movements of Western Europe are also branches of the educated bourgeoisie - i.e., of that literary public sphere that Habermas defines as the orienting ideal of the 'raisonné' audience. The uneducated 'people' of whom Habermas speaks is a projection of this very audience.

But what about the US? As you pointed out earlier, education has an exclusionary effect. After all, we know that Trump was elected primarily by people (and I'm quoting you here) "in fear and existential distress or in a panic-like state of insecurity, for whom the borders of the public sphere are closed." Trump gave this public of "uneducated and economically pessimistic villagers" a voice. And the demand upon them is:

"Act rationally!" I believe that is what Lyotard described as 'the totalitarianism of reason' in his critique of Habermas. When rationality is claimed or even admonished, the result is not rationality, but further conflict.

Maren: If you ask it like that, I think I need to be more specific. I don't know whether certain spheres or educational milieus are really factually closed, because what we observe is only the fact that this is claimed. This seems to me to be a communication-practical trick that simply equates inclusion and enforcement or exclusion and discussion. That way, someone will always claim to be excluded when they get a debate instead of confirmation. It could indeed be that this is an attendant circumstance of education, but then I would say more precisely: It is concomitant with an education oriented towards the application of knowledge and an instrumental rationality, which is always presented with an authoritarian gesture. Truth in this context is a patriarchal variant: whoever 'has' it, 'leads'. This instrumental education and this authoritarian gesture are sharply offended by discursive education - or by communication, as Habermas understands it - and that experience can make something like 'simple' truth attractive to the 'healthy' mind as a consequence. This is nothing other than the desire to finally be right without any discussion. It is certainly too seldom realized how much renunciation and humility goes hand in hand 
with education, and how tempting it is to be offered a truth that you finally and definitely show off with.

Let's turn to the concept of the sphere itself. Habermas says the public-when configured in a particular way, as in 'public relations,' "public buildings,' etc. - "presents itself as a sphere." How do you determine the area that a sphere marks, and why do you think Habermas made this conceptual decision?

Maren: As I read it, Habermas himself uses the term metaphorically at best; he describes it as something like a milieu, and then he distinguishes, as it were, the milieu that results from free access - the public sphere - from the milieu that results from restrictive access the private sphere. In both cases, he probably means something like interiors: here society, there the oikos. I have little use for the expression myself, although I like Sloterdijk's definition of "a matter of form" as form-ality quite well, because it suggests - how shall I put it? - cognition where there is intuition.

Ingrid: Again, I relate to the transnationalization of publics. Often overlooked in debates which mainly relate to the book, he has made comments regarding the internationalization of publics. For example, in his book Between Facts and Norms from 1999 he notes that public spheres represent a highly complex network that branches out into multitudes of overlapping international, national, regional, local, and subcultural arenas. He also notes a diversity of various levels of public spheres, of what he calls "episodic publics," publics of "particular events" and "abstract" publics of isolated readers, listeners and viewers scattered across target geographical areas or even around the globe, and brought together only through the mass media. However, it seems that although Habermas attempts to relate to formations of transnational publics, his notion of 'actors' is mainly articulated through 'modern' social theory, resulting in a perception of 'global' publics as a somewhat peripheral orbit revolving around the central space of modern public spheres. I feel that 'sphere,' which was used to describe a national sphere of interactions among citizens, is today reduced to what I call 'interactive' axis. These include direct civic interactions among citizens from different countries, but could also involve, referring to Latour, other 'actors.' These are new phenomena, and we are only in a first stage of conceptualizing these new processes of deliberation. The next phase would be to address these in ethical and moral contexts, and the need to ask what 'reasoning' means within them.

In order to do justice to the change in the function of the public sphere, in 1990 Habermas resorted to another very suggestive metaphor: network, instead of sphere. If we are going to use a metaphor instead of a concept at all, should we maybe leave 'sphere' behind in favor of the 'net' to describe the public?

Ingrid: I suggest leaving sphere behind, at least in this normative sense. We have to adopt new perspectives to be able to assess current realities of public discourse. Network is a useful term and clearly relates back to Castells, who already saw two decades ago all states transitioning to 'Network States' challenging traditional societal institutions. He also spoke about the power of 'nodes' in globalized networks. Latour's model allows us to make 'epistemic' connections across varying sets of 'actors.' Both models are useful. I use interactive 'axis' in my approach because digital communication is today managed on a subjective level; we manage apps on our smart phones, manage our communicative relations and our types of networks to engage with politically. The Townhall meetings of the past are gone and are replaced by interactive social media. Today, the power of tech monopolies as nodes in public communication is something very unique to our time, and this needs to be made visible conceptually.

Maren: Habermas's concept of the net is not only metaphorically suggestive, but also fashionable, to a certain extent. This was already true in 1990. I don't trust such noun 
$\mathrm{K}$

50,4

986

substitutions in the mode of advancing knowledge. Why should we give up any term or expression - leave it behind, discard it? It is rather a matter of specifying and contextualizing. Then - and now I am using the term myself - a network of terms referring to each other will emerge, none of which can be used as a super-formula of an age. There is also the warlike economic metaphor of expansion; if, as White has emphasized for decades, networks have no spatial boundaries - i.e., if they are not 'spherical' - then they can't expand at all. Luhmann's concept of system is much more effective because it refers to a selfdesigning difference, world society is understood as such a self-designing difference. The problem to be described and understood, it seems to me, is compression, not expansion. What we very abruptly call 'hate speech,' for example, is such a form of compression - a tension or stress effect - of communication. It is possible that the public sphere today is not a cheerful raisonné, if it ever was, but rather a very tense form of highly temporalized observation of communication - a form of condensation.

What other aspects of the current structural transformation of the public would be conceivable?

Maren: Differentiation theory would assume that every system form changes when its environment changes, but each in its own way. Moreover, it would assume that systems can privilege certain variants of their own, and thus also that politics and mass media can become captivated by each other - so to speak - in the sense that particularly variant-rich structural forms appear on both borders. Then that could be summarized or standardized under the name of the public sphere. In terms of network theory, you would also assume that where a particularly high communication effort is made, a particularly productive difference exists; and the most productive forms of difference are uncertainties, insecurities, ambivalences. The structural change we are looking for might simply consist in this situational productivity. It would not be in the fact that one dominant structure is replaced by another dominant structure, but in the fact that in certain places very many forms of uncertainty - and in others, very few - occur simultaneously, and with them also very many - or very few - forms of dealing with uncertainty. It would certainly be difficult to establish collective commitment at such apotheoses. But if that is the purpose of politics, then the question of the structural change of politics or the public can be answered - as Latour might say - by searching for traces in the thicket of uncertainties. I can imagine that what has been called the reference problem of organization since Herbert Simon - i.e., uncertainty absorption - has become the reference problem of politics. At the same time, the organization - at least in the form of bureaucratically observing formal membership - is becoming less plausible.

Ingrid: I feel that we need new conceptual approaches, a new vocabulary. The current terms we have in social sciences, in political science and in media and communication are not sufficient to grasp the core new 'figurations'-to use Norbert Elias' term - of public communication. For example, people still use the term media; Markus, you are even referring to 'mass' media. We do not know what 'media' are today. Linear media, yes television, etc. But how about Netflix? How about Youtube or Whats App? How about clouds and apps? Everyone can produce content, and we see how 'influencers' on Youtube are becoming leaders with thousands of followers in all types of debates - in trivial contexts, but also in political contexts. These are new phenomena, rarely addressed, yet, very influential. These types of power require new terms. For example, the way that we communicate via apps requires a new terminology; that Apple is providing international political news platforms also requires a rethinking of our traditional vocabulary. These processes change societal communication, and it is time to move conceptually into these new territories of public interaction. 
Some sociologists like Andreas Reckwitz return to the concept of class.

Ingrid: Yes, but he does not work with Marx's but rather with Bourdieu's concept of class.

Maren: Which in the German tradition corresponds more with Geiger's concept of stratum.

But would you agree that classes are real because there are social strata alongside segmental and functional ones, which are set and kept unequal by political and economic structures? Think about the growing upper class, which no longer invests its wealth productively, but in segregating luxury instead.

Maren: Although I'm concerned with the problem, I'm not concerned with the concept of social inequality. I find the concept under-complex, but not the problem itself. Marx's concept assumes an economic basis of society, which I find theoretico-strategically impressive and elegant, but also very narrow-minded.

Ingrid: And it is simply historically outdated, because it has the industrial society in mind.

And Bourdieu's take on class?

Maren: His term implies a cultural or cultural-political bias that makes me uneasy because it works with such strong, fateful determinations, and also cultivates a certain zoological curiosity, which I see - I'll say it bluntly - as a seduction to condescension, and compensatory as a seduction to a quasi-fighting, obtrusive compassion. This does not convince me at all. If so, then Marx - to think about the digitalized world society with the same theoretical determination and elegance - is sociologically appealing. I'm not at all interested in the consumer habits of the various social classes. I'm very interested in the formal variants of work (Marx again) and even more so in the formal variants of communication about work (Luhmann). But then, you have to abstract far more resolutely than is necessary if you want to sort out the coffee houses of Berlin's creative chicory. I find that boring.

Ingrid: In my work class is not an issue, but I address stratification processes in terms of transnational digital public interaction across societies. The Westernization of digital communication has been addressed earlier, but it is also the issue of a new digital divide we are currently facing. While citizens of some countries are able to engage with global risks, others who are the most affected are not. Especially vis-a-vis global risks (and the current crisis illuminates this further), there are new stratification processes in terms of risk communication emerging. I also see a generation-specific stratification process happening at the moment wherein young citizens across countries fully engage in digital interaction while older generations are much less included. In this sense, we need a new focus on generational stratification in societal communication.

Do you think you can honor Habermas by coming to a consensus at the end of this interview? What concept of the public can you agree on?

Maren: No, no consensus! Because why? What would be the point of that? To never have to talk to each other again?

Ingrid: I feel that we both have slightly different approaches, and I do not see a need to 'agree.' Discourse and dialogue enabled by interviews like this keep scholarly debate alive and interesting! To agree means to close shop and go home. I don't want to do that, but prefer active engagement to be able to address - together with colleagues like Maren and others - crucial issues of our time. Among these, public interaction across societies in times of global crisis, and of new dimensions of Artificial Intelligence and other new technologies is one of the most important topics. So hopefully we have more opportunities for dialogue and debate! 
$\mathrm{K}$

50,4

988
Last question: What effects does the pandemic have on the public sphere? What shifts can be observed here?

Maren: I observe an interesting sensitivity for autological, self-referential structures on the one hand, and a disturbing affinity for traditional forms of management on the other. On one hand, the virus behaves as if it had seen - for instance - Steven Soderbergh's Contagion and knows we have, too; it knows our steps before we take them. As a result, our future has suddenly become a tangible implication of our present; the future, as Luhmann noted decades ago, cannot begin because it has already begun. This creates something like a fascinated paralysis. And this paralysis seems to me to find its medial expression in the frozen immobility with which we stare at the presence-simulations of our screens - so far, by the way, without a sense of the complication that arises from the fact that most of these screens are touch screens. On the other hand, the spread of the virus is viewed as a duplicate of mass media networks with which traditional administrations have been competing for a long time. The virus is admired because it realizes the inclusion imperative of modern society almost perfectly: everyone can be affected - nobody can't be. But as for the other side of this admiration, there is a need for action that has to prioritize, prefer, select in order to prevail. The viral boundlessness is countered with relevance hierarchies that discredit everything that appears as a variant of the virus: the foreign, the incomprehensible, the restless. It seems to me that the slogan of the executive hour is diabolical - particularly for the public sphere.

Ingrid: This crisis clearly reveals not only a global health crisis, but also the limitations of territorial conceptions of civic interaction. Civic interaction which, however, is enabled by globalized content platforms which generate citizens' data. The national focus of digital policy - the national perspective is also included in intergovernmental debates, such as by the U.N. or the OECD - cannot address transnational regulation of these content monopolies, and has for too long turned a blind eye to these phenomena. The Cambridge Analytica scandal was a wake-up call for many governments that realized the power of manipulated data over public opinion formation. In today's crisis, Google and social media in addition to Zoom are the key hubs of crisis communication on a global scale. This should be seen as another wake-up call to commence a discussion about new types of digital policy initiatives to safeguard civic interaction in times of globalized crisis.

Prof Dr Maren Lehmann, Chair for Sociological Theory in the Department of Cultural and Communication Sciences at Zeppelin University. Her work is concerned with the sociology of organisation, in particular the theory of individuality and career and the theory of decision, design theory, and the sociology of religion. Recent topic-related publications: "Enthemmter Dissens: Kommunikation in Netzwerken", (Disinhibited dissent: communication in networks), Koch, L./König, T. (Eds., 2020), Zwischen Feindsetzung und Selbstviktimisierung. Gefühlspolitik und Ästhetik populistischer Kommunikation (Between hostility and self victimization. Emotional politics and aesthetics of populist communication), pp. 203-226; »Angstkommunikation in dichten Ordnungen. Über Terror und Terrorismus (Fear communication in dense orders. About terror and terrorism), in: Soziale Systeme 21(1), 2016 (publ. 2018).

Prof Dr Ingrid Volkmer, Head, Media and Communications, University of Melbourne. Her work has a focus on digital communication and technologies in a globalized context with a focus on civic interaction and digital policy. She has published widely in these areas, such as The Global Public Sphere. Public Communication in the Age of Reflective Interdependence (2014) and The Transnationalization of Public Spheres and Global Policy, The Oxford Handbook of Global Policy and Public Administration (2019). She has held Visiting Positions at Harvard, the LSE, University of Amsterdam and has been appointed to 
the 'International Panel on Social Progress' along with two hundred internationally leading scholars to draft policy guidelines for governments worldwide regarding global challenges of the 21 st Century.

The Other Spheres:

\section{A Postscript}

At about the same time as I was editing this interview, Michael Hofmann's contribution to this issue reached us. The co-editors and I decided to present him with the passage dealing with the two spheres Habermas named, but did not explore further. How might this plea for a modification and reconsideration of these two sphere concepts be viewed by an expert on Habermas's distinctions?

Michael, do you think that we should pay more attention to both the "plebeian" and the "regimented" public spheres that Habermas - back in 1961 - cast aside in favour of the liberal model of the public sphere?

Yes, I agree with that. However, both definitions cannot be directly applied to, for instance, Trump's counter-public and, respectively, to China's regimented public sphere.

How would you relate these new types of spheres to the ones Habermas talked about?

On one hand, the populist movements in Western Europe can hardly be called educated, let alone enlightened in the sense of Habermas's concept of the "literary public sphere." On the other hand, as you well know, Trump's counter-public in the United States does not only consist of "uneducated, economically pessimistic villagers." And from my perspective, the demand to "Act rationally!" does not necessarily degrade the person who is addressed that way. The irrational behavior, with its bias against the findings of the natural sciences, that to a significant extent defines Trump's counter-public, can literally decide matters of life or death. For example, the Republican State Assembly candidate for that district in Wisconsin that contributed 14,000 votes to Trump's winning margin of 23,000 in 2016 is a restaurant owner who refuses to recommend - let alone mandate - that anybody wear face masks on his premises. As a result, one of the restaurant's waitresses contracted Covid-19 and subsequently infected her husband. Four days after she was hospitalized, her husband also had to be admitted to the hospital, where he died. In short, the scholarly analysis of Trump's counter-public is a rather urgent one.

Would you mind giving it a try? What, in your view, is the main difficulty of applying Habermas's concepts to the current phenomena?

Well, the first question is whether his 1962 definition of a "plebeian public sphere" can be applied to Trump's counter-public, which has been emerging since June 2015 when he entered the Republican primaries as a candidate for the United States Presidency. The second question is whether Habermas's parallel definition of "the plebiscitary-acclamatory form of regimented public sphere" can indeed be applied to China and Russia today. The third question is whether both are only "variants of the public sphere of bourgeois society," which is defined by its liberal model based on the Kantian maxim about the public use of reason by private people who own private property and thus have the means to acquire an education.

The difficulty of applying Habermas's 1962 definitions results from their inherent complexity and, partially, from their lack of differentiation. During the Jacobin phase of the French Revolution, the "plebeian public sphere" adopted Rousseau's democratic ideal of equality in a community of small property owners. Hence, Habermas's claim that its "continued but submerged existence manifested itself in the Chartist movement and especially in the anarchist traditions of the workers' movement on the continent" is incorrect. The Chartist movement already privileged communal over private property, and
Interview with Maren Lehmann and Ingrid Volkmer

989 
$\mathrm{K}$

50,4

990

the response of the labor movement to the capitalist mode of production was to call for the public ownership of the means of production.

This distinction is directly applicable to the present situation in the United States. Nancy Fraser, a leading theoretician of the public sphere concept, distinguishes between Trump's right-wing authoritarian populism and the left-leaning democratic populism of Bernie Sanders. In this context, the next contradiction in Habermas's 1962 "Author's Preface" becomes highly relevant. On one hand, he defines the "plebeian public sphere" as "illiterate." On the other hand, he calls it - in terms of intellectual history - an heir to the Enlightenment tradition of the $18^{\text {th }}$ century.

It is correct that in 2016 the decisive $0.07 \%$ of all votes that triggered Trump's victory in the Electoral College were cast by citizens in Michigan, Wisconsin, and Pennsylvania without college degrees. The question is whether they constitute "a public of uneducated, economically pessimistic villagers," to quote your ironic inversion of Maren Lehmann's description of a publicity that does only exist for "educated, economically confident urbanites".

The union members who disregarded the pleas of their leaders and voted for Trump were mostly duped by him. In short, they lacked the enlightened reasoning needed to realize that he was a demagogue, cherry-picking union positions like the opposition to the TransPacific Partnership (TPP).

Trump's counter-public is thus dependent on the absence of rational-critical thinking. Otherwise its blue-collar members would realize that behind his anti-immigration and anti-China rhetoric, Trump actually strengthens the powers that be. In comparison, the counter-public formed on social media by the Bernie Sanders movement sought to educate and enlighten the "99\%" of American voters about the inner workings of these power structures - especially about the translation of economic into political power. In that regard, it would come closest to the notion of a "plebeian public sphere" in the Enlightenment tradition.

In other words, while Trump's counter-public shares its fundamental dependence on private property with "the liberal model of the bourgeois public sphere," it lacks its equally basic reliance on education; the Bernie Sanders counter public privileges education and enlightenment, but critiques the private ownership of the means of production within the tenets of democratic socialism. In short, neither one can indeed be correctly identified as a variant of "the liberal model of the bourgeois public sphere."

This analysis can also be applied to the "populist movements of Western Europe." Maren Lehmann calls them "branches of the educated bourgeoisie." It is correct that there are a few educated leaders of right-wing populist parties, especially in Germany. However, like Trump, who is turning the Republicans into such a party, most of them do not like to read and educate themselves. Above all, Lehmann is mistaken when calling them enlightened in the sense of Habermas's concept of the "literary public sphere."

Moreover, the distinction between being educated and being enlightened is especially relevant when looking at "the plebiscitary-acclamatory form of regimented public sphere" in today's China. There can be no doubt that China's so-called "Communist" leadership puts a premium on educating its work force. By the same token, it does everything in its power to keep the people, in whose name it pretends to rule, unenlightened. That is why those who advocate Kant's public use of reason immediately end up in jail or worse.

In 1962, Habermas did not apply his definition of "the plebiscitary-acclamatory form of regimented public sphere" to the People's Republic of China or to the Soviet Union, because as a variant of "the public sphere of bourgeois society," it has to be based on the constitutional right to private property. He talks about "highly developed dictatorships in industrial society," the dictatorship like the one in Franco's Spain, Mussolini's Italy, or 
Hitler's Germany. The German case especially illuminates why Habermas did not define such a "regimented public sphere" as "illiterate," but rather as "post-literary"; the worst crimes against humanity in the twentieth century were committed in the name of the people of one of the most highly educated nations. Since China's Stalinist Capitalism is dependent on strictly regimented private property owners, its concentration camps follow in the German tradition, and thus have to be distinguished from the Stalinist Gulags in a so-called "Communist" society, in which private property was outlawed.

As these reflections demonstrate, Habermas's definition of the "plebeian public sphere"

Interview with Maren Lehmann and Ingrid Volkmer in his 1962 "Author's Preface" can serve as a starting point for the urgent discussion of Trump's authoritarian populism, but it is too contradictory to precisely capture the complex nature of his counter-public which, after all - at least from my perspective - was created by corporate media in pursuit of ratings and profits.

\section{Notes}

1. This moment of irrationality may be the reason for Habermas's continual refusal to agree to an English translation of the debate. Michael King, who, with two colleagues, had planned to publish an English version, thinks "that he [Habermas, M.H.] was maybe embarrassed to have misunderstood and misrepresented Luhmann so badly in his criticisms and was concerned about his public image in Anglo-Saxon countries, particularly the USA, where is was regarded as something of a hero of the left" (Michael King in an e-mail to me, 20 November 2020, M.H.) The letter that King showed me seems to prove his point, with Habermas implicitly admitting that his criticism was inappropriate (by pointing at the "later and more appropriate" one inThe Discourse of Modernity). But it is his suggestion that King should devote himself to translating previously unpublished Luhmann texts instead that is most revealing: "This social theorist does not need an instrumentalization of my name for achieving his well-deserved reputation in the Anglophonic world." (Fax from 2nd June 2010) To see a translation as (yet another) extension of social technology is quite remarkable, to say the least.

2. Both theories seem to owe their temporal design equally to Husserl's construction of consciousness. Here, too, the concrete present cannot dispose of itself because it can only become conscious of the system in retrospect. Grosso modo: Consciousness can never be 'now,' in Luhmann's words: it operates with its back to the future, reflexively; it moves against time into the past, constantly seeing itself from behind, where it has already been (Luhmann, 1995, 63) and yet a structure emerges, a passage of higher expectability - classically: organised complexity. However, as Füllsack also points out, this compatibility does of course not mean that their theories are commensurable. Luhmann would most likely deny Habermas membership in the club of contemporary social theorists; for him, the theoretical implementation - formally: the reentry - of one's own blind spot is the prerequisite for leaving tradition behind (2012, p. 110 f.). For him, science is as sustainable as it is able to relate to itself.

While it is true that Habermas - who is well aware of the normative character of his theory, as Maren Lehmann also emphasises in this interview - is not interested in such a re-entry because it makes visible the moment of production not least of validity, it is at least questionable to what extent Luhmann was successful here. A theory has no consciousness and therefore cannot turn back on itself. The inventor of the re-entry, Spencer-Brown, had failed at implementing it into his calculus (Heidingsfelder et al. 2021). And even if it should be clear that Luhmann, in contrast to Habermas, repeatedly relativises his own observational perspective and opposes an overheating with "hypothermia": The claim that only theorists with a built-in re-entry have left tradition behind is also nonnegotiable i.e. has not yet re-entered itself.

Anyone who builds in self-reference must reckon with contradictions. Contradictions in a theory can - but do not have to - lead to everything being true and false at the same time, so one can no longer make any meaningful statements, for instance about a contradictory theory. Whoever says 
$\mathrm{K}$

50,4

992

"I know that I know nothing" knows something, thus contradicts herself. Whoever demands to tolerate everything demands that one must also tolerate zero tolerance, because 'everything' also includes intolerance. In this sense, Luhmann's theory can at least be considered considerably more tolerant of the social phenomena it observes than that of Habermas, who, with recourse to the supposed normative nature of communication, rejects certain social forms as inadmissible or misguided. By contrast, nothing social is alien to Luhmann - except maybe those theories to which certain social forms are alien. (Some observers would disagree: Everything social is alien to Luhmann, which is precisely what makes him such an excellent theorist. But that is yet another story.)

3. I was informed of this by Luhmann's former assistant Peter Fuchs, but Habermas apparently enjoyed telling the story as well. Uwe Schminank can hardly hold back in his Luhmann obituary: "The light figure of the left and the - seemingly - arch-conservative play with each other - not against each other! - table tennis. This story has shaped my sense of political tolerance more lastingly than anything else." (1999, p. 137 f., transl. M.H.)

4. These considerations are the result of a long discussion with Dirk Baecker - whom I would like to thank explicitly at this point - which probably would not have happened without a corresponding change of sphere.

5. See also the introduction to this issue, which discusses these questions in greater detail.

\section{References}

Baecker, D. (1996), “Oszillierende Öffentlichkeit "(The oscillating public)”, Maresch, R. (Ed.), Medien und Öffentlichkeit: Positionierungen, Symptome, Simulationsbrüche (The media and the public: positionings, symptoms, simulation breaks), Boer, Munich, pp. 89-107.

Füllsack, M. (1998), "Geltungsansprüche und Beobachtungen zweiter Ordnung: Wie nahe kommen sich Diskurs- und Systemtheorie?" (Claims of validity and second-order observations: How close are discourse theory and systems theory?), Soziale Systeme, Vol. 4 No. 1, pp. 185-198.

Goode, W.J. (1960), "Norm Commitment and Conformity to Role-Status Obligations", American Journal of Sociology, Vol. 66 No. 3, pp. 246-258.

Habermas, J. (1984), Vorstudien und Ergänzungen zur Theorie des kommunikativen Handelns (Preliminary studies and additions to the theory of communicative action), Suhrkamp, Frankfurt am Main.

Habermas, J. (1996), Die Einbeziehung des Anderen. Studien zur politischen Theorie (The inclusion of the other. Studies on political theory), Suhrkamp, Frankfurt am Main.

Habermas, J. and Luhmann, N. (1971), Theorie der Gesellschaft oder Sozialtechnologie - Was leistet die Systemforschung? Theorie-Diskussion (Theory of Society or Social technology - What is Systems Research Achieving? A Discussion of Theory), Suhrkamp, Frankfurt am Main.

Heidingsfelder, M., Lehmann, M. (Eds), (2020), Corona - Weltgesellschaft im Ausnahmezustand? (World society in a state of emergency?), Velbrück, Weilerswist.

Heidingsfelder, M., Zeiner, P., Ooi, K.J.A. and Bhuiyan, M.A.S. (2021), "Marking the Mark. George Spencer Brown's Operator Across the Disciplines", Roth, S., Heidingsfelder, M., Clausen, L., Laursen, K.B. (Eds), George Spencer Brown's "Design with the Nor": with Related Essays, Emerald, Bingley, pp. 91-142.

Lakatos, I. and Musgrave, A. (Eds), (1970), "Criticism and the growth of knowledge", Proceedings of the International Colloquium in the Philosophy of Science, London, 1965, Cambridge UP, Cambridge, Vol. 4.

Lüdemann, S. (1998), "Die Solidarität von Staat und Raum. Politische Grenzen, soziologische Grenzen, Körpergrenzen" (The solidarity of state and space. Political borders, sociological borders, 
physical borders), Honegger, C., Hradil, S. and Traxler, F. (Eds), Grenzenlose Gesellschaft? (A society without borders?), Leske and Budrich, Freiburg, pp. 359-369.

Luhmann, N. (1993), "Quod omnes tangit... Anmerkungen zur Rechtstheorie von Jürgen Habermas. Aus Anlaß von Jürgen Habermas, Faktizität und Geltung: Beiträge zur Diskurstheorie des Rechts und des demokratischen Rechtsstaats, Frankfurt a.M.: Suhrkamp 1992", (Remarks on Jürgen Habermas's legal theory), Rechtshistorisches Journal, Vol. 12, pp. 36-56.

Luhmann, N. (1995 [1984]), Social Systems, Stanford UP, Stanford.

Luhmann, N. (2002), Die Politik Der Gesellschaft (Politics of society), Suhrkamp, Frankfurt am Main.

Lyotard, J. (1986), Das postmoderne Wissen, Ein Bericht (Postmodern knowledge. A report), edited by P. Engelmann, Böhlau, Wien.

Nietzsche, F. (1999), "Über die Zukunft unserer Bildungsanstalten. Sechs öffentliche Vorträge" (About the future of our educational institutions. Six public lectures)", Colli, G. and Montinari, M. (Eds), Kritische Studienausgabe (Critical study edition), de Gruyter, München, pp. 641-752.

Schimank, U. (1999), "Ein widerspenstiger Lehrer" (A subordinate teacher)", Bardmann, T. M. and Baecker, D. (Eds), "Gibt es Eigentlich Den Berliner Zoo Noch?” Erinnerungen an Niklas Luhmann (Does the Berlin Zoo actually still exist? Memories of Niklas Luhmann), Konstanz, UVK, pp. 137-142.

Simmel, G. (1992a [1908]), "Der Raum und die räumlichen Ordnungen der Gesellschaft” (Space and the spatial orders of society), in: Gesamtausgabe (Collected Works) 11: Soziologie. Untersuchungen über die Formen der Vergesellschaftung (Sociology. Studies on the forms of socialization),), Suhrkamp, Frankfurt am Main, pp. 687-698.

Simmel, G. (1992b [1908]), “Der Streit” (Conflict)”, in: Gesamtausgabe (Collected Works) 11: Soziologie. Untersuchungen über die Formen der Vergesellschaftung (Sociology. Studies on the forms of socialization), Suhrkamp, Frankfurt am Main, pp. 186-255.

Prof Dr Michael Hofmann, School of Communication and Multimedia Studies, Florida Atlantic University. Recent Publications: Habermas's Public Sphere: A Critique. Lanham, MD: Fairleigh Dickinson University Press/Rowman and Littlefield, 2017 (Paperback: 2019); "Deliberation in Dysfunctional Democracies: The Global Need for Critically Renewing Habermas's Public Sphere Concept.", The Journal of Communication and Media Studies, Vol. 4 No. 3, 2019, pp. 47-67; "Habermas's Public Sphere versus Trump's Twittersphere: Citizenship in a World of Social Media", The Journal of Communication and Media Studies, Vol. 3 No. 4, 2018, pp. 1-19. Next Book Publication: Reading Habermas's Structural Transformation of the Public Sphere: A Critical Guide. Lanham, MD: Lexington Press/Rowman and Littlefield (Spring 2022).
Interview with Maren Lehmann and Ingrid Volkmer

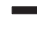

